\title{
STUDI POTENSI SUMBERDAYA PETERNAKAN DI KABUPATEN MAMBERAMO RAYA
}

\section{STUDY OF POTENTIAL LIVESTOCK RESOURCES IN MAMBERAMO RAYA REGENCY}

\author{
Lukas Yowel Sonbait ${ }^{1)}$ dan Yustina L. D. Wambrauw ${ }^{2)}$ \\ 1) Staf Pengajar Jurusan Peternakan Fapet UNIPA \\ 2) Staf Pengajar Jurusan Agribisnis Faperta UNIPA \\ Jalan Gunung Salju Amban Manokwari, 98314
}

Article history

Accepted: May 4, 2018 ;

Approved: June 1, 2018

* Corresponding author:

E-mail:

lukas.sonbait@gmail.com

\section{ABSTACT}

The objective of this research was to determine the potential resource of farms in Mamberamo Raya regency. The research was conducted in the Mamberamo Raya Regency between September and October 2012., A subjective approach of the qualitative method was used by interview and literature studies. The results showed that the livestock development in Mamberamo Raya regency had a promising future, but worth noting agribusiness channel from upstream to downstream. The problem faced by farmers was lack of venture capital, livestock, training, lack of access to education and short of affordable of quality health services, low investment both public and companies, lack of basic infrastructure such as roads, electricity, limited good river transport services, problem of land and sea linkages among districts and limited access to marketing. To optimize the efficiency of the production value and income of farmers then this should be supported by a cooperative storage facility or the expected distribution of the production can be accommodated and prepared collectively. Regional development of cattle and goats have good prospects in Mamberamo Hulu district, Central Mamberamo, Benuki, Roufaer, Mamberamo Lower and Upper Waropen. Other commodities need to be developed in all districts in Mamberamo are Pigs, Goats, range chicken and duck. Buffaloes also prospective by considering the potential freshwater swamps but the presence of natural predators such as estuarine crocodile and the annual flooding of Mamberamo should be considered. Livestock production is a priority at the moment in order to meet local consumption and improve animal protein sources.

Keywords: Potenty study, resource, livestock

\section{PENDAHULUAN}

Kabupaten Mamberamo Raya adalah salah satu kabupaten di Provinsi Papua yang resmi menjadi kabupaten berdasarkan UndangUndang No. 19 Tahun 2007. Kabupaten
Mamberamo Raya merupakan pemekaran dari Kabupaten Sarmi dan Kabupaten Waropen. Sejak terbentuknya Kabupaten Mamberamo Raya hingga sekarang (tahun 2009), telah terjadi perkembangan baik secara ekonomi, administrasi (pemekaran distrik) maupun 
keruangan (spasial). Kabupaten ini mempunyai luas wilayah sebesar 2.381,4 $\mathrm{Km}^{2}$ (23.813,9 Ha) atau $7,68 \%$ dari luas daratan Provinsi Papua \pm 309.934,40 km², (BPS Kabupaten Mamberamo Raya, 2012). Salah satu sektor sebagai potensi sumberdaya alam yang belum digarap secara optimal untuk pengembangan kesejahteraan masyarakat adalah sub sektor peternakan. Kabupaten Mamberamo Raya memiliki kawasan Cagar Alam Memberamo Foya yang merupakan zona penyangga (buffer zone) bagi kelestarian Sungai Memberamo yang merupakan sungai terbesar di Papua. Pada umumnya mayoritas masyarakat di Kabupaten mamberamo Raya secara umum mengusahakan babi, ayam buras, kambing, sapi dan itik. Walaupun jumlah ternaknya bervariasi, namun jika dilihat dari persebarannya maka ternak ayam buras merupakan ternak yang paling sering diusahakan secara luas oleh penduduk di seluruh distrik di Kabupaten Mamberamo Raya. Ayam buras terbanyak terdapat di semua distrik dimana pada tahun 2011 jumlahnya 680 ekor dan pada tahun 2012 meningkat menjadi 1015 ekor (Dinas Pertanian \& Perikanan Kab. Mamberamo Raya, 2012). Ternak babi merupakan jenis ternak besar yang banyak diusahakan oleh penduduk lokal dengan tujuan pada umumnya untuk konsumsi maupun untuk upacara keagamaan atau menyambut tamu. Babi, sapi maupun ternak yang potensial untuk dikembangkan. Sebagai salah satu sumber pendapatan bagi keluarga, jenis ternak besar ini sangat potensial. Pengusahaan ternak di Kabupaten Mamberamo Raya secara umum dilakukan tanpa perkandangan. Pada umumnya semua jenis ternak di lepas, walaupun demikian ada beberapa penduduk yang sudah mengandangkan ternak di halaman rumah. Sampai sejauh ini belum diketahui secara detail potensi sumberdaya ternak yang ada di daerah ini, sehingga penulis tertarik untuk melakukan suatu penelitian observasi dan studi literatur. Tujuan penelitian ini adalah:

1. Dapat memberikan informasi ilmiah pada kalangan akademisi sebagai acuan pengetahuan potensi peternakan untuk studi selanjutnya.

2. Dapat memberikan informasi awal bagi pemerintah kabupaten Mamberamo Raya dalam menyusun program pengembangan peternakan diwilayah tersebut.

\section{MATERI DAN METODE}

Penelitian ini dilaksanakan di beberapa distrik di kabupaten Mamberamo Raya yang mana distrik tersebut diambil secara purposive dengan pertimbangan memiliki potensi peternakan dan mendapatkan bantuan ternak dari pemerintah, diantaranya Mamberamo Hulu, Mamberamo Hilir dan Roufaer. Penelitian dilaksanakan pada bulan September - Oktober 2012. Penelitian ini menggunakan pendekatan subyektif dengan metode kualitatif. Pendekatan kualitatif adalah prosedur penelitian yang menghasilkan kata-kata tertulis atau lisan dari perilaku yang diamati (Moleang, 2008). Metode pengambilan data secara primer dilakukan melalui wawancara secara mendalam (Indenth interview) disertai survei langsung ke peternak lokal, lahan produktif untuk agribisnis peternakan dan petugas lapangan. Jawaban dan pengamatan dilapangan dicatat dan dinilai secara deskriptif. Untuk pengumpulan data secara sekunder diperoleh melalui instansi pemerintah serta data dari petugas lapangan terkait dengan penelitian.

\section{HASIL DAN PEMBAHASAN}

\section{Jenis-jenis Ternak yang Diusahakan}

Berdasarkan hasil survei, secara umum jenis-jenis ternak yang yang dibudidayakan oleh masyarakat pada umumnya masih dilakukan secara tradisional dengan tujuan untuk pemenuhan kebutuhan keluarga maupun sebagai hiburan (pet). Untuk jenis-jenis ternak yang diusahakan adalah ternak ayam kampung (Gallus domesticus), itik dan babi hutan (Sus verrocosus) maupun babi lokal (Sus Vittatus) sebagai sumber protein hewani dan belum diarahkan pada skala yang lebih besar karena akses pasar yang belum tersedia secara kontinyu. Ternak ini merupakan ternak utama yang diusahakan masyarakat, selain itu buaya sebagai satwa yang paling sering ditemukan justru sangat berperan dalam peningkatan pendapatan keluarga. yang dimanfaatkan kulit dan dagingnya untuk peningkatan kesejahteraan keluarga. 


\section{Teknologi Produksi, Frekuensi Produksi Pertahun Menurut Jenis Ternak}

Dalam pengembangan peternakan di wilayah Distrik Mamberamo Hulu maupun Distrik Rofaer maupun beberapa distrik di wilayah ini, pada umumnya masih menggunakan teknologi sederhana. Menurut jenisnya, pada umumnya masyarakat membudidayakan ternak babi lokal (sus vittatus), ayam kampung (Galus domesticus), sapi bali (bos sondaicus) dan kambing (capra sp) dapat dilihat pada diagram Gambar 1. Populasi Ternak potong dan unggas di
Kabupaten Mamberamo Raya tahun 2012. Berdasarkan data diatas menunjukkan bahwa populasi ternak pada umumnya belum mengalami peningkatan yang signifikan, bahkan cenderung statis. Diperlukan teknologi produksi yang lebih baik, serta pelatihan dan bimbingan teknis oleh penyuluh bagi petani peternak yang kontinyu dan berkesinambungan. Selain itu juga perlu ditambahkan bibit ternak yang berkualitas dan tenaga penyuluh yang sesuai dengan bidang keahlian yang tersebar merata ke seluruh distrik di kabupaten Mamberamo Raya.

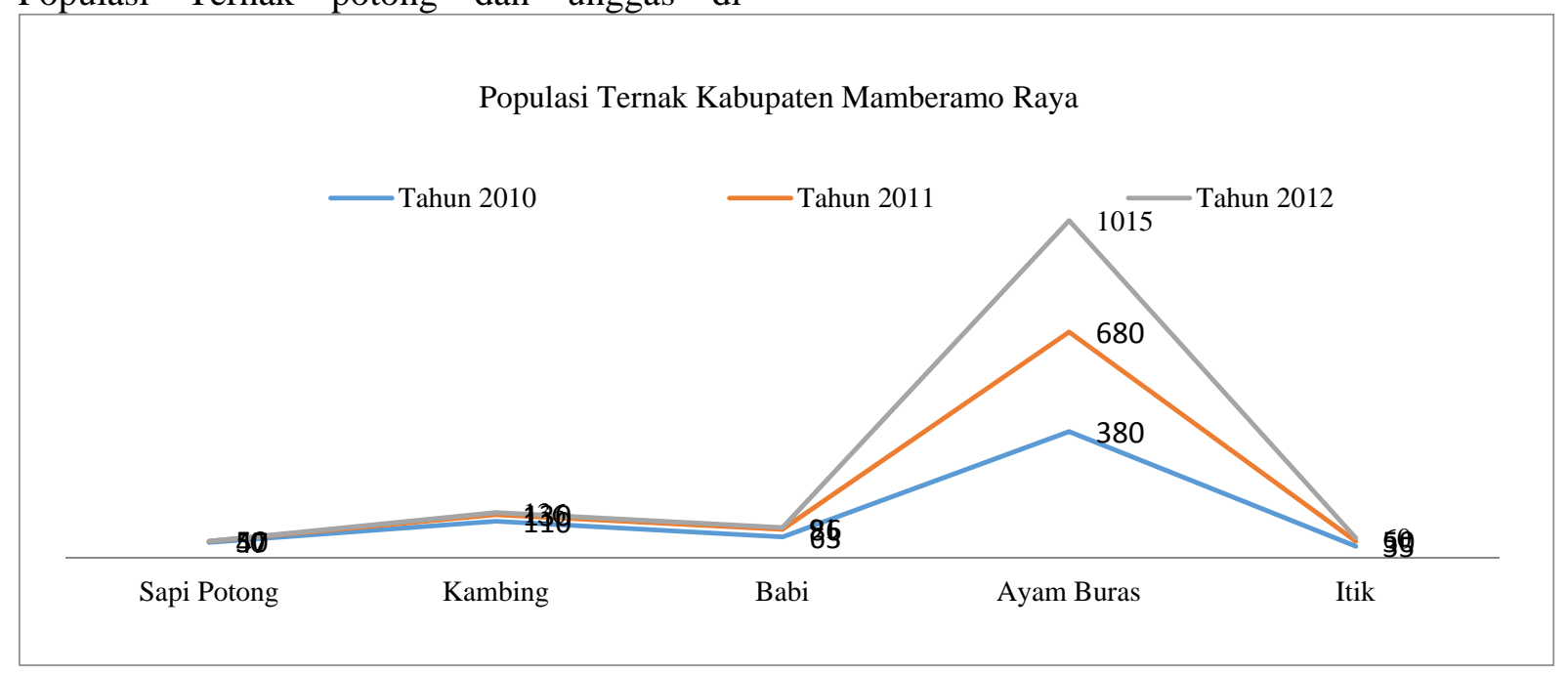

\section{Jenis-Jenis Spesifik Lokal}

Jenis-jenis hewan spesifik lokal di Kabupaten Mamberamo Raya, pada umumnya sama dengan dengan wilayah-wilayah lain di dataran tanah Papua. Salah satu jenis spesifik yang sangat potensi untuk dikembangkan antara lain buaya muara (Crocodile porossus) dan buaya darat (Crocodile novaquinea). Hal ini didukung oleh potensi sungai mamberamo yang melintasi sepanjang kabupaten ini. Selain itu, jenis-jenis hewan lain yang bisa dimanfaatkan stausnya menjadi ternak atau satwa harapan adalah babi hutan, tikus tanah, lao-lao, burung kum-kum, burung cenderawasih, mambruk (Columbidae). Beberapa jenis satwa liar diketahui sebagai sumber bahan pangan masyarakat secara lebih spesifik sebagau sumber protein hewani rumah tangga di pedalaman Papua. Jenis-jenis satwa lain yang umumnya diburu dikonsumsi oleh masyarakat, Babi hutan (Sus vittatus), Kuskus
(Phalangeridae), Kura-kura papua (Chelodina novaeguineae) Bandikut dan Biawak (Varanus salvadorii), Kuskus (Phalanger Sp), Rusa (Cervus timorensis), Soa-soa, Tikus Tanah (Pogonomeloys sp) serta beberapa jenis burung seperti Mambruk (Gaura sp), Kumkum (columbia livia), Nuri (Domicella lory), Kakaktua Putih (Cacatua galerita), Bangau Putih (Bubulcus ibis) dan Cenderawasih (parasedae sp). Babi hutan merupakan salah satu jenis satwa yang sering dijumpai, yang dipelihara masyarakat. Sebagian kelompok masyarakat memanfaatkan hewan ini untuk memperbaiki keturunan ternak babi lokal peliharaan mereka dengan cara mengumbar babi betina lokal di sekitar di hutan dan menarik perhatian babi hutan jantan yang kemudian mengawini betina lokal. Diyakini hasil persilangan kedua jenis ini mempunyai kualitas daging yang lebih baik. Pemanfaatan sebagai bahan pangan dilakukan melalui aktivitas perburuan. Pemanfaatan daging satwa-satwa ini yang utama adalah sebagai sumber protein 
hewani masyarakat. Masyarakat biasanya menggunakan teknik pengolahan daging secara sederhana dalam bentuk daging asar (atau daging asap) dengan cara menggantung daging hasil buruan di atas perapian di dapur. Selain itu jenis satwa ini diburu untuk dipelihara sebagai hewan kesenangan (pets) karena keindahan bulu, suara dan untuk hiburan di lingkungan rumah. Potensi ketersediaan jenis spesifik hewan lokal cukup besar, akan tetapi dari keadaan umum dapat dilihat bahwa tingkat konsumsi bahan pangan lokal masyarakat setempat cukup tinggi sebagai sumber protein hewani. Untuk itu pemanfaatan dan Pengembangan ternak lokal diharapkan dapat ditingkatkan dan dijaga kelestariannya agar jangan sampai punah.

\section{Teknologi Produksi bagi Jenis Ternak Spesifik Lokal}

Teknologi produksi yang digunakan bagi jenis-jenis ternak spesifik lokal oleh masyarakat di wilayah ini menurut pengamatan tergolong masih sederhana. Alat - alat yang digunakan dalam penangkapan hewan spesifik lokal seperti perburuan mambruk, kasuari soasoa maupun buaya dan lain sebagai masih menggunakan peralatan seadanya seperti parang, cangkul/pacul, parang, sabit, tali, nelon, kapak dan kalawai. Teknik pemeliharaan ternak seperti penangkaran buaya masih dilakukan pada skala rumah tangga, untuk industri penyampakan buaya dapat ditemui di Distrik Mamberamo Hulu. Dua jenis buaya yang sering dijumpai da DAS Mamberamo yakni buaya muara (Crocodile porossus) dan Buaya darat (Crocodile novaquinea), juga berhabitat di sungai yang memiliki lebar terbesar di Indonesia. Kedua spesies-buaya ini menjadi perburuan bagi masyarakat tradisional, khususnya dari suku Bauzi. Cara berburunya juga khas. Pada masa lalu, untuk menangkap buaya beberapa pria harus menyelam. Alat yang dipakai hanya tali rotan. Kini, sudah setelah mengenal beradapan, masyarakat lokal telah selangkah lebih maju, Mereka menggunakan tombak (dao) dan kail untuk memburu buaya. Daging hasil perburuan itu dikonsumsi. Sedangkan kulitnya dijual dengan harga bervariasi sesuai dengan umur dan ukuran tubuh. Pada ternak babi lokal (sus vitattus), masyarakat telah menggunakan kandang baik kandang panggung untuk tempat beristirahat maupun kandang tanah untuk bermain.

\section{Permasalahan yang Dihadapi Masyarakat Terhadap Komoditi Peternakan}

Dari hasil pengamatan dan wawancara pada beberapa peternak yang harus diselesaikan pada komoditi peternakan adalah perlu adanya pelatihan maupun magang kepada petani peternak sebelum pengadaan berbagai jenis ternak, petugas penyuluh harus ditingkatkan dan harus disebarkan merata di masing-masing Distrik untuk mendukung pelayanan kepada masyarakat, Sarana transportasi harus dibenahi, sehingga memudahkan dalam pelayanan maupun proses penjualan hasil ternak, Pengadaan bibit ternak unggul serta penyiapan kandang ternak serta penyediaan hijauan makanan ternak khususnya bagi ternak sapi dan kambing, Perlu sosialisasi kepada distrik maupun kampung yang masyarakatnya belum pernah memelihara ternak, Pemerintah bersedia membeli produk peternakan yang di kelola masyarakat (Koperasi) serta Perlu dilakukan pelatihan mengenai pengolahan hasil ternak dengan menggunakan teknologi sederhana.

\section{Pola Produksi, Konsumsi, dan Pemasaran Hasil Ternak}

Pola-pola produksi, konsumsi dan distribusi komoditi diwilayah pengamatan relatif sangat terbatas. Keterbatasan tersebut disebabkan karena akses perhubungan antara lokasi satu ke lokasi lainnya cukup sulit. Hal ini merupakan faktor penghambat utama. Selain itu biaya transportasi yang tinggi serta akses yang terbatas menambah permasalahan dalam pola konsumsi dan pemasaran hasil ternak. Dari segi usaha produksi dan konsumsi sebagian masyarakat setempat hanya berorientasi pada pemenuhan kebutuhan keluarga, sementara pola produksi serta konsumsi yang mengarah pada komersialisasi belum nampak pada aktivitas peternakan bahkan pertanian secara umum. Persentase pola distribusi hasil peternakan sebagian besar hanya dilakukan didaerah setempat, sementara sebagian kecil 
dari produksi yang dihasilkan didistribusikan keluar daerah kampung. Jenis komoditi pertanian yang distribusinya dapat keluar dari kampung adalah jenis ternak babi dalam jumlah terbatas. Pola distribusi hasil peternakan yang dibawah ke daerah lain menggunakan boat maupun penerbangan. Dari informasi yang diperoleh bahwa pola distribusi hasil peternakan dilakukan dalam dua cara yaitu dengan dijual didalam daerah kampung atau dijual ke kampung lain. Rata-rata harga daging buruan adalah Rp. 25.000,-/kg.

\section{Kontinuitas Produksi, Konsumsi dan Pemasaran Hasil Ternak}

Selama ini kontinuitas produksi dan konsumsi masyarakat terhadap produk peternakan merupakan masalah utama. Hingga saat ini hampir seluruh komoditi hasil peternakan masyarakat tidak mengarah pada orientasi pasar kecuali untuk peternakan buaya walaupun pembudidayaannya jarang, namun buaya dimanfaatkan kulitnya untuk dijual. Harga kulit buaya rata-rata dengan umur 4-6 bulan adalah Rp. 30.000 perinchi. Berdasarkan pengamatan dilapangan pemasaran kulit buaya sebelumnya dijual kepada perusahaanperusahaan kayu dimasa lalu. Saat ini masyarakat menjualnya ke Kampung Dabra sebagai ibukota distrik Mamberamo Hulu ataupun pedagang yang langsung membeli di lokasi. Untuk jenis ternak seperti ayam kampung rata-rata masyarakat belum memanfaatkan sebagai ternak untuk memperoleh pendapatan. Untuk ternak babi jika produksi meningkat bisanya dipasarkan ke kampung yang memiliki jumlah penduduk lebih banyak atau langsung di bawah ke Kasonaweja atau ke kabupaten Sarmi. Hal ini dirasakan sangat mempengaruhi pendapatan, karena jarak ke lokasi pasar yang jauh maupun biaya transportasi yang tinggi sehingga tidak efisien dalam pengelolahan hasil ternak. Produksi peternakan yang diutamakan oleh masyarakat mamberamo saat ini adalah untuk konsumsi lokal dalam rangka pemenuhan dan peningkatan gizi yang bersumber dari protein hewan (daging dan telur). Keikut sertaan pihak swasta khususnya investor sangat diharapkan untuk tujuan komersial. Selain itu juga peran stakeholder dalam peningkatan produksi sangat diperlukan terutama dengan diadakan pelatihan-pelatihan menyangkut sistem pemeliharaan ternak, ketersediaan penyuluh lapangan serta pemberian bibit ternak yang sesuai dengan kondisi di daerah.

\section{Jumlah dan Aset Produksi bagi Ternak}

Dalam pengembangan sub sektor peternakan sebagai bagian penting dari pertanian, aset merupakan salah satu modal dasar dalam mendukung pengembangan potensi peternakan itu sendiri. Jenis-jenis aset peternakan yang dimiliki oleh masyarakat di Distrik Roufaer adalah dibagi dalam 3 bentuk yaitu peralatan, modal dan lahan. Untuk peralatan, masyarakat menggunakan parang, sabit, kapak, jenis peralatan lainnya yang merupakan jenis peralatan yang sangat berharga bagi masyarakat setempat sehingga hampir setiap keluarga memiliki peralatan ini. Umumnya peralatan ini dibeli di pasar Kasonaweja atau dari Kabupaten Sarmi dan kabupaten Jayapura dengan harga berkisar antara 75.000-100.000/buah untuk jenis parang/sabit, sementara harga jual kapal biasanya lebih mahal yaitu berkisar antara 200.000-250.000/buah tergantung jenis dan ukurannya. Bentuk modal yang merupakan asset bagi masyarakat setempat adalah lahan dan uang. Untuk modal lahan tidak ditemukan suatu kendala yang berarti karena ketersediaan lahan untuk membuka lahan kebun sangat tersedia, rata-rata untuk satu kepala keluarga memiliki luasan kebun berkisar antara 1- 2 Ha dengan komposisi tanaman yang diusahakan lebih dari satu jenis, sehingga dapat juga dimanfaatkan sebagai tempat peternakan. Sementara itu modal dalam bentuk uang biasanya merupakan milik perorangan atau kelompok.

\section{Kelembagaan Formal dan Non Formal serta Organisasi yang Berkaitan dengan Pengadaan, Distribusi dan Pengolahan Hasil serta Pemasaran Hasil Ternak}

Kelembagaan formal maupun non-formal di distrik Roufaer dan distrik Mamberamo Hulu pada umumnya untuk wilayah pengamatan telah terbentuk. Berdasarkan laporan dari dinas Pertanian dan keluatan melalui subdin Peternakan Kabupaten Mamberamo Raya, 
jumlah kelompok ternak babi sebanyak 25 kelompok dan kelompok ternak unggas sebanyak 58 kelompok yang tersebar di distrik Mamberamo Tengah, Roufaer dan Mamberamo Hulu. Namun data tersebut masih berdasarkan proposal yang masuk ke dinas. Dalam pengamatan dilapangan rata-rata petani memiliki ternak secara pribadi, dengan manajemen pasca dan produksi yang masih sederhana. Kelembagaan yang dibentuk oleh peternak adalah atas dasar prakarsa masyarakat setempat dengan manajemen pengelolaan yang sederhana. Sampai sekarang usaha peternakan unggas maupun ternak babi masih dilakukan sendiri.

\section{Peternakan Berkaitan dengan Pengadaan dan Distribusi Saprotan, Pengolahan Hasil serta Pemasaran Hasil Ternak}

Berdasarkan hasil pengamatan dilapangan, pengembangan sub sektor peternakan sampai sejauh ini masih berjalan lambat dan belum begitu dirasakan oleh masyarakat. Salah satu penyebabnya adalah letak geografis yang berbukit, rawa dan pesisir pantai yang membentang luas tanpa didukung oleh sarana dan prasarana produksi peternakan. Sehingga pengolahan hasil dan pemasaranpun masih sangat terbatas untuk konsumtif maupun antar sesama masyarakat yang mendiami dataran Mamberamo Raya. Untuk itu sudah saatnya pemerintah daerah melakukan tindakan pengadaan dan penyebaran segala sarana pendukung pengembangan ternak baik berupa pengadaan bibit ternak, pelatihan dan magang bagi peternak lokal, penyediaan tenaga penyuluh yang memiliki skil, mengembangkan industri-industri peternakan rakyat secara berkelanjutan.

\section{Jumlah Penyuluh Peternakan Menurut Kualifikasi Pendidikan dan Pengalaman Kerja}

Menurut Rogers, everett (1976), penyuluh merupakan seseorang atas nama pemerintah atau lembaga penyuluh yang berkewajiban mempengaruhi proses pengambilan keputusan yang dilakukan oleh sasaran penyuluhan untuk mengadopsi suatu inovasi. Berdasarkan hasil pencacahan sensus penduduk 2012 (Dinas
Kependudukan dan Pencatatan sipil Kabupaten Mamberamo Raya, 2012). Jumlah penduduk kabupaten Mamberamo Raya adalah 27.070 Jiwa yang terdiri dari 14.453 laki-laki dan 12608 perempuan. Apabila dilihat dari jumlah PPL, kabupaten Mamberamo raya memiliki 5 orang PPL dengan kualifikasi pendidikan, sarjana (S1) 1 orang, D3Peternakan 2 orang dan D3 Keswan sebanyak 1 orang di tambah dengan beberapa tenaga penyuluh lulusan SMA dan sederajat yang tersebar di 5 Distrik untuk menangani 87 kelompok petani ternak dengan status kelas pra pemula dan pemula. Kualifikasi dan jumlah PPL yang sangat minim jika dibandingkan dengan luasan wilayah kabupaten yaitu sebesar 2.381,4 Km² (23.813,9 $\mathrm{Ha}$ ) yang tersebar di 8 distrik, merupakan masalah mendasar yang harus segera diperhatikan pemerintah daerah. Dari hasil wawancara yang dilakukan kepada penyuluh, masalah utama yang dihadapi adalah biaya operasional yang sangat rendah sehingga mereka tidak mampu menjangkau seluruh wilayah yang menjadi area tugas. Penyuluh merupakan Opinion leaders sebagai media penyebar adopsi inovasi kepada masyarakat, tanpa mereka pembangunan peternakan di suatu wilayah hanya bersifat statis. Tenaga penyuluh yang berkualitas baik jumlah dan mutu sangat di perlukan di Kabupaten Mamberamo Raya, sehingga pengembangan ternak kecil, ternak besar maupun unggas bisa ditingkatkan.Penyuluh sebagai motor pembangunan di kampung, perlu secara bertahap merubah mutu sumber daya manusia (SDM) peternak dalam rangka pengembangan agribisnis peternakan melalui; Pembinaan transformasi pola pikir (mindset) peternak tradisional yang perilaku belum intensif pada usaha ternak. Petani peternak di mamberamo raya bahkan daerah lain di Papua masih berstatus pengelola multi usaha dan tidak spesifik pada salah satu jenis usaha. Hal ini tidak sejalan dengan jiwa dan entrepreneurship pelaku agribisnis peternakan. Penyuluh harus melakukan pembinaan teknis pemeliharaan ternak para peternak yang mengarah kepada intensifikasi bisnis, serta pelatihan dan penggunaan teknologi pertanian 


\section{Pandangan Masyarakat Tentang Pembangunan dibidang Peternakan}

Berdasarkan hasil wawancara dengan masyarakat asli yang mendiami beberapa wilayah di distrik Rouvaer maupun Mamberamo Hulu, Hasil wawancara dengan masyarakat menunjukkan bahwa terdapat keinginan masyarakat untuk beternak hewan ruminansia (pemakan rumput) seperti sapi dan kambing atau kelinci. Hal yang menjadi kendala utama adalah masalah modal untuk membeli hewan. Namun demikian hasil pengamatan menunjukkan bahwa beternak belum menjadi prioritas. Ini terlihat dari sifat masyarakat yang hanya berharap pada pemerintah untuk mendapatkan bantuan hewan daripada membeli sendiri dengan uang sendiri. Selain itu juga akses transportasi dan pemasaran menjadi kendala utama dalam peningkatan populasi maupun produktivitas ternak. Beberapa kendala teknis yang perlu mendapat perhatian khusus selain masalah diatas adalah perlu adanya pembinaan dan pendampingan secara intensif bagi masyarakat lokal dari pihak-pihak terkait yang diharapkan dapat memberikan modal pengetahuan serta pemahaman bagi masyarakat dalam melakukan teknik budidaya ternak.

\section{Hukum Adat Yang Mengatur Tentang Pengelolahan Sumberdaya Tanah dan Ternak.}

Bagi masyarakat Mamberamo Raya, setiap suku mempunyai wilayah masing-masing. Selama ternak atau satwa masuk di dalam wilayah mereka maka dikuasai oleh suku yang bersangkutan, dengan demikian ternak yang berada di wilayah tersebut milik masyarakat yang bermukim di daerah tersebut. Hukum adat tentang pengelolaan sumber daya peternakan walaupun secara administrasi belum tertata dengan baik namun ada beberapa daerah atau kawasan tertentu yang telah diatur secara adat menurut peruntukan wilayah dan aturan-aturan adat tersebut merupakan warisan yang diturunkan dari generasi ke generasi. Ada beberapa wilayah tertentu yang merupakan kawasan pemukiman sekaligus dijadikan sebagai lahan peternakan. Pada umumnya kegiatan peternakan di kelola masyarakat masih bersifat sampingan terutama untuk memenuhi kebutuhan protein hewan. Hukum adat yang mengatur pengelolahan sumberdaya kehutanan, pertanian, peternakan dan perikanan darat yang masih ada dianggap bagian dari warisan sebelumnya. Dari informasi yang diperoleh bahwa setiap marga/fam yang menjadi pemegang hak ulayat dalam satu kampung memiliki tempat/kawasan tabu yang secara adat dilarang untuk melakukan aktivitas disekitar.

Undang-Undang, Peraturan Pemerintah dan PERDA Tentang Pembangunan Sub Sektor Peternakan

Sejak berdirinya kabupaten Mamberamo Raya hingga saat ini, regulasi yang dijalankan oleh pemerintah terkait dengan peraturan daerah atau undang-undang tentang pembangunan sub sektor peternakan masih belum nampak. Salah satu undang-undang yang sudah di garap adalah pelarangan pembunuhan jenis buaya berukuran besar oleh masyarakat. Menurut informasi yang diperoleh bahwa undang-undang, peraturan pemerintah, dan peraturan daerah tentang pembangunan pertanian belum diketahui masyarakat sehingga pengelolaan subsektor peternakan oleh masyarakat. Masyarakat pada umumnya masih mengacu pada aturan adat serta kebiasaan yang berlaku. Pemanfaatan hewan buruan oleh masyarakat pribumi umumnya tidak diatur secara sistematis sesuai dengan batas-batas wilayah sehingga mereka hanya bisa mendapatkan hasil buruan sesuai keinginan di lokasi yang mereka miliki, kecuali bagi orang luar atau marga/fam lain yang tidak memiliki hubungan kekerabatan maka pemanfaatan lahan biasanya ditempuh melalui prosedur adat dan biasanya terkait langsung dengan kelompok marga/fam asli setempat dan juga kepala kampung.

\section{KESIMPULAN DAN SARAN Kesimpulan}

Pengembangan potensi sumberdaya sub sektor peternakan di kabupaten Mamberamo Raya memiliki prospek yang cerah, namun perlu diperhatikan saluran agribisnis mulai dari hulu sampai dihilir. Masalah utama yang dihadapi oleh peternak adalah kurangnya modal usaha, bibit ternak, pelatihan-pelatihan, rendahnya akses terhadap layanan jasa 
pendidikan dan kesehatan yang bermutu dan terjangkau, rendahnya investasi baik masyarakat maupun perusahaan, terbatasnya prasarana dasar seperti seperti sarana jalan dan listrik, terbatasnya layanan transportasi baik sungai (DAS Mamberamo), darat dan laut yang menghubungkan antar distrik di Mamberamo Raya, serta terbatasnya akses pemasaran. Untuk mengoptimalkan efisiensi nilai produksi dan pendapatan peternak maka perlu ditunjang dengan fasilitas penampungan atau koperasi yang diharapkan pendistribusian hasil dapat diakomodir dan dapat dilakukan secara kolektif. Partisipasi masyarakat sangat mendukung dalam hal Pemberian tanah, lokasi usaha. Keterbukaan untuk menerima program pengembangan komoditi ternak besar seperti sapi dan kambing. Daerah pengembangan ternak sapi dan kambing yang mempunyai prospek baik adalah: Mamberamo Hulu, Benuki Mamberamo Tengah, Roufaer, Mamberamo Hilir \& Waropen Atas. Jenis komoditas lain yang perlu dikembangkan di semua Distrik di kabupaten Mamberamo Raya adalah: ternak Babi, Kambing, Ayam buras dan Itik. Produksi peternakan diutamakan untuk saat ini adalah konsumsi lokal dalam rangka pemenuhan dan peningkatan gizi yang bersumber dari protein hewan (daging dan telur). Keikutsertaan pihak swasta khususnya investor diharapkan untuk tujuan komersial.

\section{Saran}

Perlu dilakukan survei lebih lanjut untuk mengetahui potensi wilayah yang produktif untuk pengembangan peternakan serta perlu dilakukan pembinaan peternakan lokal untuk meningkatkan pendapatan dan kesejahteraan masyarakat petani melalui peningkatan produksi peternakan.

\section{DAFTAR PUSTAKA}

BPS Kabupaten Mamberamo Raya, 2012. Mamberamo Raya dalam Angka 2012. Mamberamo Raya.

Dinas Pertanian dan Perikanan Kabupaten Mamberamo Raya, 2012. Laporan Tahunan. Mamberamo Raya

Dinas Kependudukan dan Pencatatan Sipil Kabupaten Mamberamo Raya, 2012. Laporan Tahunan. Mamberamo Raya.

Rogers, Everett M. 1976. Communication in organization. New York: The Free Press.

Kuntowijoyo, 2006. Budaya dan Masyarakat. Tiara Wacana, Yogyakarta.

Moleang, L.J. 2008. Metode Penelitian Kualitatif. PT. Remaja Rosdakarya, Bandung. 